\title{
Beheersing van ziekenhuiszorg
}

De zorgsector staat onder druk. Wat traditioneel te boek stond als een deel van de publieke sector, ontwikkelt zich steeds meer tot een sector waarin mechanismen werkzaam zijn zoals men die op een imperfecte markt aantreft. Waar vroeger de professionele autonomie van medici en het vertrouwen dat 'leken' in hen stelden dominant waren, verschuift de macht nu naar buitenstaanders. Verzekeraars, (potentiële) patiënten, ziekenhuisbesturen en aan een imperfecte markt gerelateerde toezichtorganen krijgen duidelijk meer invloed. Die toenemende invloed wordt door recente wijzigingen in wet- en regelgeving gefaciliteerd en gestimuleerd.

Dit themanummer van het $M A B$ is gewijd aan de veranderingen in de beheersingsstructuren en mechanismen rond en in de ziekenhuiszorg. Het bevat zowel bijdragen van meer algemeen conceptuele aard (Groenewegen, Vosselman), als de resultaten van meer empirische studies en gevalstudies (Asselman, Brandenburg en Crom). Alle artikelen staan in de context van veranderingen, in de context van dynamiek. Die dynamiek betreft in dit themanummer:

- de kernbeweging van een zorgrelatie naar een transactionele relatie, die in feite een beweging van standaardisatie en economisering is (Vosselman),

- het ontwerp en de inrichting van (imperfecte) markten (Groenewegen),

- de verwachtingen van partijen uit het veld (verzekeraars, ziekenhuisbestuurders) omtrent de effecten van de invoering van marktwerking op transactiekosten (Brandenburg),

- de interactie tussen variëteit en complexiteit van zorgactiviteiten enerzijds en budgetsystematiek anderzijds (Crom), en

- het ontwerp en de implementatie van een kostprijscalculatiesysteem in een academisch ziekenhuis (Asselman).

Vosselman beschrijft de cruciale betekenis van de beschikbaarheid van een kostprijs voor de geleidelijke ontwikkeling naar de inrichting van een imperfecte markt voor ziekenhuiszorg. Een kostprijs geeft informatie die het middelenbeslag op zorgactiviteiten (gericht op een bepaald zorgproduct) representeert. Zo'n representatie is een symbool dat niet alleen reflectieve eigenschappen heeft, maar ook in staat is om zorgactiviteiten vanaf een afstand te helpen construeren. Die laatste eigenschap maakt de kostprijs tot een potentieel machtsinstrument in handen van buitenstaanders, de overheid en de tot marktpartijen benoemde verzekeraars (en indirect de patiënten). Die macht kan worden uitgeoefend op verschillende manieren, bijvoorbeeld via processen van 'benchmarking' en via de inrichting van een imperfecte markt. Dat heeft doelmatigheidsvoordelen, maar 'instrumentaliseert' ook het werk van de medisch professional met mogelijk kwaliteitsverlagende effecten. Zo bezien hebben standaardisatie en economisering ook hun prijs.

Groenewegen biedt een transactiekostentheoretisch perspectief op de veranderingen in het beheersingssysteem rond ziekenhuiszorg. Hij laat zien dat de beheersingsstructuur transactiekosten met zich meebrengt en dat die kosten onder andere afhankelijk zijn van de aard van de activiteiten. Zij bestaan onder andere uit administratie- en registratiekosten, kosten van onderhandelingen en kosten voor het oplossen van conflicten. Zij worden gedragen door de direct betrokken partijen zoals verzekeraars en ziekenhuisbesturen en staan voor een deel in relatie tot het bestrijden van opportunistisch gedrag. Voorts zijn er kosten verbonden aan de oprichting, werking en instandhouding van noodzakelijke toezichthoudende organen. Groenewegen besteedt ook aandacht aan de wederzijdse relatie tussen de beheersingsstructuur en de institutionele context. De laatste bestaat onder andere uit professionele waarden- en normenpatronen, maar ook uit meer concrete wet- en regelgeving. 
Ook Brandenburg laat zich informeren door de transactiekostentheorie en neemt meer in het bijzonder de contractering tussen zorgverzekeraars en ziekenhuizen onder de loep. Zij doet verslag van een empirisch onderzoek onder ziekenhuisbestuurders en zorgverzekeraars. Het onderzoek levert een beeld op van een gedeeld verwachtingspatroon tussen beide groepen. Zowel ziekenhuisbestuurders als verzekeraars verwachten een sterke stijging van de transactiekosten als gevolg van de invoering van marktwerking. Verzekeraars zullen vooral gaan investeren in informatiesystemen, in 'benchmarking' en in hun 'inkoopfunctie. Voorts verwachten beide partijen dat marktwerking realiseerbaar is voor planbare zorg met hoge volumes, lage risico's en meetbare resultaten. En, 'last but not least', beide groepen hebben zeker geen hoge verwachtingen over de terugtreding van de overheid en bijbehorende deregulering.

Crom haakt niet aan bij de economische organisatietheorie, maar baseert zijn onderzoek op de in de jaren tachtig en negentig in zwang geraakte contingentiebenadering in het wetenschappelijk (accounting)onderzoek. Hij rekent vooral af met een uit deze benadering afkomstig inzicht dat het ontwerp van een budgetteringssysteem onder andere afhankelijk is van de mate van taakonzekerheid (de mate van variëteit in activiteiten en de complexiteit van die activiteiten). Uit zijn gevalstudie blijkt dat een veelheid aan (subjectieve) factoren de inrichting van het budgetsysteem verklaart. Voorts blijkt eenduidig dat taakonzekerheid geen onafhankelijke variabele is in een functionele relatie met de inrichting van het budgetsysteem. De afdelingen met een relatief lage taakonzekerheid worden niet meer met een rekenkundig budget ofwel outputbudget geconfronteerd dan afdelingen met een relatief hoge taakonzekerheid. Eerder vindt Crom aanwijzingen voor een omgekeerde relatie: de wens dan wel noodzaak om tot outputbudgettering te komen heeft gevolgen voor de taakonzekerheid. De taakonzekerheid wordt daarmee in feite een afhankelijke variabele. Eenheden worden via rekenkundige budgetmechanismen onder druk gezet om de complexiteit van zorgactiviteiten te reduceren en zo veel mogelijk te standaardiseren.

Tegen de achtergrond van de introductie van marktwerking in de gezondheidszorg geeft Asselman inzicht in het proces dat tot een kostprijsinformatiesysteem in een academisch medisch centrum heeft geleid. Voor alle relevante medische activiteiten worden jaarlijks kostprijzen vastgesteld. Asselman laat zien hoe de kostprijzen die in het begin alleen voor financieel-administratieve doelen werden gebruikt geleidelijk ook een 'stuurinstrument' voor medisch specialisten werden. Die specialisten gebruiken de kostprijsinformatie onder andere bij de optimalisatie van de zorgportfolio en bij de beoordeling van de doelmatigheid van nieuwe behandelingen. Dat leidt er vervolgens wel toe dat er steeds hogere eisen worden gesteld aan de kwaliteit van de kostprijs. Voorts worden eisen gesteld aan de kennis en vaardigheden van de gebruikers van de kostprijzen.

Alles bij elkaar geven de in dit themanummer opgenomen artikelen een aardig inzicht in de bewegingen die zich in de beheersingsstructuren en -processen rond de ziekenhuiszorg afspelen. De toekomst zal moeten leren in hoeverre de doorgevoerde en nog door te voeren veranderingen inderdaad tot meer doelmatigheid leiden onder handhaving of liefst verbetering van het kwaliteitsniveau. In dat verband zal er ongetwijfeld nog veel onderzoek plaatsvinden.

Ed Vosselman

Redacteur 